\title{
Inflammatory Mediators Regulate Cathepsin S in Macrophages and Microglia: A Role in Attenuating Heparan Sulfate Interactions
}

\author{
John P. Liuzzo, ${ }^{1}$ Suzana S. Petanceska, ${ }^{2}$ David Moscatelli, ${ }^{3}$ and \\ Lakshmi A. Devi ${ }^{1}$ \\ Departments of ${ }^{1}$ Pharmacology, ${ }^{2}$ Cell Biology, and ${ }^{1,2}$ Kaplan Cancer \\ Center, New York University School of Medicine, New York, New \\ York, U.S.A. \\ ${ }^{3}$ Dementia Research Group, Nathan Kline Institute at New York \\ University, Orangeburg, New York, U.S.A. \\ Accepted March 26, 1999.
}

\begin{abstract}
Background: Cathepsin S is a member of the family of cysteine lysosomal proteases. The distribution of cathep$\sin \mathrm{S}$ is restricted to cells from the mononuclear lineage both in the brain and in the periphery. Also, its protease activity is uniquely stable at neutral $\mathrm{pH}$.

Materials and Methods: We compared the expression of cathepsin S, B, and L mRNAs in various undifferentiated and differentiated cells of mononuclear origin, and examined the modulation of these mRNAs by inflammatory mediators (lipopolysaccharide and various cytokines). In addition, the effect of these agents on cathep$\sin \mathrm{S}$ protein levels and protease activity was also determined. Lastly, the ability of cathepsin S to process basement membrane components such as heparan sulfate proteoglycans in vitro and in vivo was assessed.

Results: Cathepsin S, B, and L mRNAs are expressed in mature macrophages and microglial cells and not in undifferentiated monocytes. Activators of macrophages
\end{abstract}

negatively regulate all three transcripts. Consistent with this, treatment with these agents leads to a decrease in intracellular cathepsin $S$ protein levels and activity. However, the same treatments result in stimulation of secreted cathepsin S activity. Cathepsin S is capable of degrading heparan sulfate proteoglycans in vitro. Also, when expressed in endothelial cells, cathepsin S autocrinely attenuates the basic fibroblast growth factor (bFGF)-mediated binding of FGF receptor containing cells to endothelial cells, by acting on basement membrane proteoglycans.

Conclusions: Taken together, these data imply that cathepsin $S$ is a regulatable cysteine protease that plays a role in the degradation of extracellular proteins, whose secretion from macrophages and microglia is increased by signals that lead to activation of these cells, and may be important in regulating extracellular matrix interactions.

\section{Introduction}

Mononuclear phagocytes are mobile, long-lived cells of bone marrow origin that form a resident population in many tissues of the body and play central roles as effector cells in inflammatory

Address correspondence and reprint requests to: Dr. Lakshmi A. Devi, MSB 411, Department of Pharmacology, New York University Medical Center, 550 First Avenue, New York, NY 10016, U.S.A. Phone: 212-263-7119; Fax: 212-263-7133; E-mail: lakshmi.devi@med.nyu.edu reactions and cell-mediated immune responses $(1,2)$. Some examples are alveolar macrophages in the lung, Kuppfer cells in the liver, sinus histiocytes in the spleen, and microglia in the central nervous system (CNS). In response to external stimuli resident macrophages become "activated" (3). Inflammation, wound healing, and host defense against microbes or tumors represent scenarios in which activated resident macrophages and blood-borne monocytes, which are 
recruited into the tissue and differentiate, can influence the structure and composition of their environment.

Macrophage activation is a complex, multistep process that ultimately results in enhanced ability of the macrophage to phagocytose and kill foreign cells $(2,4)$. Activation signals include cytokines and growth factors (secreted by macrophages themselves, or other cells such as reactive astrocytes, $\mathrm{T}$ cells, fibroblasts, endothelial, smooth muscle, and Schwann cells), bacterial endotoxins, contact with extracellular matrix (ECM), and a variety of chemicals. Following activation, macrophages have been shown to secrete a wide variety of biologically active products, including neutral and acid proteases, that are important mediators of the tissue destruction and fibrosis characteristic of chronic inflammation $(3,4)$. Secreted acid hydrolases are derived from a preformed store contained in lysosomes, and are released rapidly, frequently within 4-6 $\mathrm{hr}$ after exposure to activating agents, while the release of neutral proteinases (elastase, plasminogen activators) is usually delayed for $24 \mathrm{hr}$ (3). Although the aspartyl proteinase cathepsin D has been well studied during macrophage activation, the role of released cysteine lysosomal cathepsins upon macrophage and microglial activation is relatively unknown.

The cysteine lysosomal proteases include cathepsins $\mathrm{B}, \mathrm{L}, \mathrm{H}, \mathrm{S}, \mathrm{O}$, and $\mathrm{K}$. Of these, only cathepsin $\mathrm{S}$ retains activity after prolonged incubation at neutral $\mathrm{pH}$, whereas all the others become irreversibly inactivated (5-7). It is this fact that makes cathepsin $S$ unique and a good candidate for tissue destruction and remodeling of the ECM in nonacidic extracellular environments (8). It has been demonstrated previously that cathepsin $S$ is able to degrade a number of components of ECM (9-12). We and others have previously demonstrated that cathepsin S expression is highly restricted to cells of the mononuclear-phagocytic system, including microglia (11-13).

Here we examine the regulation of cathepsin $S$ at the mRNA and protein level, in macrophages and microglia, by inflammatory mediators, as well as the regulation of cathepsin $B$ and $L$ mRNAs. We demonstrate that the expression of cathepsin S, cathepsin B, and cathepsin L mRNAs, and cathepsin $S$ activity are regulated by lipopolysaccharide and cytokines. In addition, we show that Perlecan, a basement membrane heparan sulfate proteoglycan (HSPG), can be degraded by cathepsin $S$ in vitro. Heparan sulfate proteogly- cans, including those of the basement membrane, can serve many functions, e.g., adhesion, as a binding site for proteases, and regulation of growth factors such as basic fibroblast growth factor (bFGF) (14-16). Thus, the secreted cathepsin $S$ from cells may potentially regulate bFGF function by attenuating its binding to HSPG, particularly to that of the basement membrane type.

\section{Materials and Methods}

\section{Cell Culture and Treatments}

Murine macrophage-like cell line RAW 264.7 (gift from Dr. S. Gandy, Nathan Kline Institute at NYU, Orangeburg, NY) and murine microglial cell line N13 (gift from Dr. P. Ricciardi-Castagnoli, University of Milan) were cultured in Dulbecco's modified Eagle medium (DMEM) and RPMI 1640 medium, respectively, each supplemented with $10 \%$ fetal bovine serum (FBS; Gibco, BRL, Gaithersburg, MD; Atlanta Biologicals, Norcross, GA), $100 \mathrm{U} / \mathrm{ml}$ penicillin $\mathrm{G}$, and $100 \mu \mathrm{g} / \mathrm{ml}$ streptomycin at $37^{\circ} \mathrm{C}$. The blood cell lines HL60, U937, K562, DAMI, KG-1, THP-1, and WEHI-3B were cultured in RPMI 1640 medium as described previously (17). For enzyme assays and mRNA experiments involving 24-hr long treatments, $1.5 \times 10^{5}$ cells/well in 24 -well plates or $2.0 \times 10^{6}$ cells in $60-\mathrm{mm}$ dishes, respectively, were cultured as above for $24 \mathrm{hr}$. Cells were washed 3 times with sterile phosphatebuffered saline (PBS) and all treatments were performed in macrophage serum-free medium (MSFM) (Gibco, BRL) in the absence or presence of the following recombinant agents: lipopolysaccharide J5 strain (LPS; Sigma, St. Louis, MO), phorbol-12-myristate-13 acetate (PMA; Sigma), human tumor necrosis factor alpha, (TNF- $\alpha$; UBI, Lake Placid, NY), murine interferon gamma (IFN- $\gamma$; Boehringer Mannheim, Indianapolis, IN), human interleukin-l alpha (IL- $1 \alpha$; Genzyme, Cambridge, MA), murine interferon alpha, (IFN- $\alpha$; Calbiochem, San Diego, CA), murine granulocyte macrophage-colony stimulating factor (GM-CSF; gift from Dr. E. L. Wilson, NYU Medical Center, New York). For time course experiments, cells were initially plated in MSFM for $24 \mathrm{hr}$, washed with PBS, and then stimulated with fresh MSFM in the presence or absence of $30 \mathrm{ng} / \mathrm{ml}$ LPS for various durations. The primary alveolar macrophages (gift from Dr. M. Lesser, Mount Sinai School of Medicine, New York) were plated in MSFM at $5 \times 10^{6}$ cells $/ 100-\mathrm{mm}$ 
dish. For dose response to LPS, cells were treated with $0,10,100$, or $1000 \mathrm{ng} / \mathrm{ml}$ LPS for $4 \mathrm{hr}$. For time course experiments, cells were treated with LPS $(100 \mathrm{ng} / \mathrm{ml})$ for 0,30 , and $120 \mathrm{~min}$. Chinese hamster ovary $(\mathrm{CHO})$ cells were maintained in DMEM supplemented with $10 \%$ FBS, bovine aortic endothelial (BAE) cells were maintained in $\alpha$ MEM supplemented with $10 \%$ calf serum, and 32D-FGFR-1 cells $(18,19)$ were maintained in Iscoves medium supplemented with $10 \%$ FBS and $10 \%$ WEHI conditioned medium, which is a source for IL-3.

\section{RNA Isolation and Northern Blot Analysis}

Total RNA was isolated from primary rat alveolar macrophages using the RNeasy kit (Qiagen, Chatsworth, CA). Fifteen to twenty micrograms of total RNA was fractionated on $1 \%$ agarose gels containing $2.2 \mathrm{M}$ formaldehyde, $0.2 \mathrm{M}$ MOPS, and $10 \mathrm{mM}$ EDTA and transferred onto Gene Screen Plus membranes (DuPont NEN, Boston, MA) via capillary action. Membranes were hybridized to $\left[{ }^{32} \mathrm{P}\right]$-radiolabeled cDNA probes as described previously (20). The membranes were exposed to a phosphor screen and quantitative analysis of mRNA bands was performed on a phosphorimager (Molecular Dynamics, Sunnyvale, CA); results were standardized to membranes probed with $18 \mathrm{~S}$ rRNAs.

\section{Synthesis of Radiolabeled cDNA Probes}

Portions of the cathepsin S (502 bp), cathepsin B (570 bp), and cathepsin L (495 bp) rat coding sequences were subcloned into the Smal site of the pGEM3zf + vector (21). The pS/E plasmid contains the DNA sequence within the Sall/ EcoR 1 fragment of $18 \mathrm{~S}$ rRNA gene (18). The recombinant plasmids were digested with EcoRI/ PstI in the case of cathepsin S, HindIII/EcoRI in the cases of cathepsins B and L, and Sall/EcoR I in the case of 18S rRNA. The DNA fragments were resolved on $1 \%$ low-melting-point agarose gels, excised, and labeled with ${ }^{32} \mathrm{P}$ dCTP $\alpha$ ] utilizing random primers and the Klenow fragment of $E$. coli DNA polymerase I (New England Biolabs, Beverly, MA).

\section{Western Blot Analysis of Cathepsin S Protein}

Polyclonal antiserum generated in rabbits to a synthetic peptide containing the sequence spanning the C-terminal 14 amino acids of rat cathep$\sin S$ protein was used. This antiserum was not able to immunoprecipitate native cathepsin $\mathrm{S}$ from cells or conditioned medium, but efficiently detected increasing amounts of denatured cathepsin $\mathrm{S}$ at $25 \mathrm{kDa}$ in a linear manner from RAW and N13 lysates. For determination of possible cross-reactivity of this antiserum to cathepsins $B$ and $L$, we immunoblotted $1 \mu \mathrm{g}$ each of purified recombinant forms of human cathepsin S (gift from Dr. D. Bromme, Mount Sinai School of Medicine), human cathepsin B (Sigma), and human cathepsin L (Calbiochem, La Jolla, CA) by $12 \%$ SDS-PAGE and performed Western analysis as described previously (17). We did not detect any cross-reactivity with recombinant human cathepsin L or B under the conditions used. For N13 microglia or RAW macrophage experiments, cells were treated with LPS or IFN- $\gamma$ for $24 \mathrm{hr}$, proteins were extracted as described (17), and equal amounts of each extract were analyzed by Western blotting as described previously (17). Signals were detected either by iodinated protein $\mathrm{A}\left(0.2 \mathrm{mCi} / \mathrm{ml}\right.$ of ${ }^{125} \mathrm{I}$-protein $\left.\mathrm{A}\right)$ or by enhanced chemiluminescence (DuPont NEN). Specific bands were quantified by phosphorimager.

\section{Cathepsin S Activity Determination}

Enzymatic assays were performed as previously described (11) with modification. Conditioned media (C.M.) were collected from treated cells, centrifuged at $16,000 \times g$ for $1 \mathrm{~min}$, transferred to new tubes, and frozen at $-20^{\circ} \mathrm{C}$ until use. Cells were lysed in $200 \mathrm{ml}$ of $10 \mathrm{mM}$ sodium acetate buffer pH 5.5, 2 mM EDTA, $0.01 \%$ Triton $\mathrm{X}-100,1 \mu \mathrm{M}$ PMSF, and $5 \mu \mathrm{M}$ pepstatin A, collected with a rubber scraper, and frozen at $-20^{\circ} \mathrm{C}$ until use. The lysates were subjected to a neutral $\mathrm{pH}$ incubation step prior to cathepsin-S activity determination; this step has been shown to inactivate other lysosomal proteases with substrate specificity similar to that of cathepsin $S$ $(7,9)$. For this, lysates $(10 \%)$ were sonicated and then incubated with neutral $\mathrm{pH}$ buffer $(0.1 \mathrm{M}$ Tris-Cl, pH 7.5, 2 mM EDTA, 2 mM DTT, $0.01 \%$ Triton $\mathrm{X}-100,1 \mu \mathrm{M}$ PMSF, $5 \mu \mathrm{M}$ pepstatin A) in a 96-well plate for $1 \mathrm{hr}$ at $37^{\circ} \mathrm{C}$. Since other proteases secreted during the 24-hr cellular treatments become inactivated by the neutral $\mathrm{pH}$ medium, C.M. was not subjected to the above preincubation. The C.M. (10\%, plus neutral pH buffer to standardize conditions) or the lysates were then incubated at $37^{\circ} \mathrm{C}$ with of $0.1 \mathrm{M}$ sodium phosphate buffer $(1: 1 \mathrm{v} / \mathrm{v}), \mathrm{pH} 6.6$, containing 2 mM EDTA, 2 mM DTT, $0.01 \%$ Triton 
$\mathrm{X}-100,1 \mu \mathrm{M}$ PMSF, $5 \mu \mathrm{M}$ pepstatin $\mathrm{A}$, and 20 $\mu \mathrm{M}$ of substrate $N$-carbobenzoxy-Phe-Arg-7amido-4-methylcoumarin (Z-FR-AMC; Sigma). The product formed was detected at excitation $383 \mathrm{~nm}$ and emission $460 \mathrm{~nm}$ on a Fluoroskan II plate reader. Inclusion of $10 \mu \mathrm{M}$ of the active site-directed inhibitor E64 (Sigma) in parallel samples was used to specifically determine cysteine protease activity.

\section{Cathepsin S Proteolysis of Basement Membrane Heparan Sulfate Proteoglycan In Vitro}

To test enzyme activity the synthetic substrate Z-FR-AMC (Sigma) was incubated with recombinant human cathepsin S (gift of Dr. D. Bromme, Mount Sinai School of Medicine) at various enzyme dilutions over a rapid time course in a neutral buffer containing $100 \mathrm{mM}$ sodium phosphate, $\mathrm{pH} 7.5,2 \mathrm{mM}$ EDTA, $2 \mathrm{mM}$ DTT, $1 \mu \mathrm{M}$ PMSF, $5 \mu \mathrm{M}$ pepstatin $\mathrm{A}$, and $0.01 \%$ Triton X-100 at $25^{\circ} \mathrm{C}$. For proteoglycan digestion, 1 or $2 \mu \mathrm{g}$ of heparan sulfate proteoglycan (HSPG; Collaborative Biomedical Products, Bedford, MA) was incubated with recombinant human cathepsin $\mathrm{S}$ in the above sodium phosphate buffer including inhibitors at either $\mathrm{pH} 6.5$, or $\mathrm{pH}$ 7.5, with or without E64 at $37^{\circ} \mathrm{C}$ for $2.5 \mathrm{hr}$ or 1.5 hr. Following termination of the reaction by an excess of E64, some reaction mixtures were subjected to heparitinase (Sigma) treatment, were heated at $95^{\circ} \mathrm{C}$ for $5 \mathrm{~min}$, and resolved on SDS polyacrylamide gels and visualized by silver staining.

\section{Ligand Blotting of Cell-Derived HSPGs}

Wild-type and transfected BAE cells were plated at $6 \times 10^{5}$ cell $/ 35-\mathrm{mm}$ dish for $24 \mathrm{hr}$, washed three times with PBS, and pretreated with activated cathepsin S (see above) in PBS for $3 \mathrm{hr}$ on a shaker at $25^{\circ} \mathrm{C}$. Following pretreatment, the cells appeared viable under the light microscope and none were detached. The cells were lysed in PBS containing $1 \%$ Triton X-100 containing 2\% glycerol, $0.1 \mu \mathrm{g} / \mathrm{ml}$ aprotinin, $0.1 \mu \mathrm{g} / \mathrm{ml}$ leupeptin, and $20 \mathrm{mM}$ EDTA. Proteins were separated by SDS-PAGE on $3-15 \%$ gels, transferred to polyvinylidene difluoride (PVDF) membranes by wet-transfer method utilizing $0.1 \%$ SDS in the buffer, and blots were incubated in BLOTTO with $1 \mu \mathrm{g} / \mathrm{ml}$ of ${ }^{125} \mathrm{I}-\mathrm{bFGF}$, with or without $10 \mu \mathrm{g} / \mathrm{ml}$ of heparin, for $12 \mathrm{hr}$ at $4^{\circ} \mathrm{C}$. Blots were washed of unbound ligand using PBS and PBS-Tween 20 and exposed to phosphorimager screens.

\section{Expression of Cathepsin S in Cell Lines}

Cells were stably transfected with the full-length rat cathepsin S cDNA (21) in a mammalian expression vector, pcDNA3 (Invitrogen, Carlsbad, CA) using Lipofectamine reagent (Gibco BRL) according to manufacturer's instructions.

\section{Cell Attachment Assays}

Determination of 32D-FGFR-1 cells' bFGF-dependent attachment to an adherent layer was performed as previously described (18). Briefly, CHO cells were plated at $5 \times 10^{5}$ cells per $35-\mathrm{mm}$ dish. After $18 \mathrm{hr}$ at $37^{\circ} \mathrm{C}$, the cells were washed two times with PBS and fixed with $3 \%$ glutaraldehyde in PBS for $2 \mathrm{hr}$ at $4^{\circ} \mathrm{C}$. Glycine was added to a final concentration of $0.01 \mathrm{M}$ to quench the reaction, and the fixed cells were washed twice with PBS and used for experiments. For a typical experiment, $5 \times 10^{5} 32 \mathrm{D}$-FGFR- 1 cells in serumfree medium plus $0.2 \%$ WEHI-conditioned medium were added to washed monolayers of $\mathrm{CHO}$ cells in the presence or absence of $10 \mathrm{ng} / \mathrm{ml}$ of bFGF. After incubation at $37^{\circ} \mathrm{C}$, medium was removed, and the monolayers were washed twice gently with PBS to remove unattached cells. The medium and PBS washes were combined. The attached cells were removed with a brief wash with PBS containing $10 \mathrm{mM}$ EDTA and $10 \mu \mathrm{g} / \mathrm{ml}$ heparin. The unattached and attached cells were counted with a Coulter particle counter. Results are presented here as [attached cells/(unattached cells + attached cells)] $\times 100$.

\section{Results}

We have previously shown that cathepsin S mRNA exhibits restricted distribution and is expressed in different populations of macrophages in the periphery and in microglia in the brain $(11,20,21)$. Consistent with this is the finding that cathepsin $S$ expression has been demonstrated in alveolar macrophages and in monocyte-derived macrophages after differentiation $(12,22)$. Cathepsin $S$ is not expressed in other glial cells, such as type 1 astrocytes or O2A progenitors, nor in neuronal cell lines, whereas cathepsin B and L are widely expressed (20).

To examine if other blood-derived cells express cathepsin S, we performed Northern analysis on total RNA from various cell lines. Of the cell lines tested (macrophage, RAW 264.7; microglial, N13; monocytic, HL60, U937, WEHI, KG-1 and THP-1; erythro-megakaryo-granulo- 
cytic, K562; and megakaryocytic, DAMI) we found cathepsin $\mathrm{S}$ expression only in the macrophage, RAW 264.7, and in the microglial, N13, cell lines as a $1.4 \mathrm{kB}$ mRNA (Fig. 1 A). None of the other blood cell lines tested exhibited detectable mRNA for cathepsin S. In addition, only RAW 264.7 macrophages and N13 microglia expressed detectable levels of $2.2 \mathrm{kB}$ cathepsin B (Fig. 1B) or $1.7 \mathrm{kB}$ cathepsin L mRNA (data not shown). These data suggest that the cysteine lysosomal proteases are expressed at significantly high levels only in the mature macrophage-like cells and not in immature monocytes. In support of our findings are the observations that cathepsin B mRNA expression was detected in THP-1 cells that were primed with phorbol ester, and cathepsin L mRNA and protein have not been detected in U937 cells nor in undifferentiated THP-1 cells (23-25).

Next we investigated whether RAW 264.7 macrophages and $\mathrm{N} 13$ microglial cells would modulate the expression of cathepsin $\mathrm{S}$ in response to activating signals. To investigate changes in the cathepsin S mRNA, we treated the cells with various doses of the macrophage activator LPS for $24 \mathrm{hr}$ and analyzed the mRNA levels by Northern blotting. Specific radiolabeled cDNA probes were utilized to detect cathepsin $\mathrm{S}$, cathepsin B, and cathepsin L, and normalized to the levels of $18 \mathrm{~S}$ rRNA. We found that treating RAW or N13 cells with LPS for $24 \mathrm{hr}$ dosedependently decreased the levels of all three mRNAs. LPS at the highest concentrations decreased cathepsin S mRNA in RAW macrophages to about $40 \%$ and in N13 microglia to $53 \%$ that of control cells not treated with LPS (Fig. 2A, B). The levels of cathepsin B mRNA were decreased by LPS in macrophages and microglia to $18 \%$ and $50 \%$, respectively (Fig. 2A, B). Treatment of microglia with $100 \mathrm{ng} / \mathrm{ml}$ of LPS decreased cathepsin L mRNA to $21 \%$ that of untreated cells (data not shown). Examination of the time course of cathepsin S, cathepsin B, and cathepsin $\mathrm{L}$ mRNA regulation by $30 \mathrm{ng} / \mathrm{ml}$ of LPS in RAW 264.7 macrophages showed that within $4 \mathrm{hr}$ of LPS treatment, there is a substantial decrease in all three mRNAs to about $30 \%$ that of control treatments (MSFM without LPS) (Fig. 3). After 8 hr of LPS treatment, compared to control treatments, the cathepsin mRNAs remained at a low level. LPS had a similar effect on rat primary alveolar macrophages; it led to a decrease in cathepsin S (Fig. 4A) and cathepsin B mRNA (not shown) in a dose-dependent fashion. The observed decrease in cathepsin S mRNA oc-
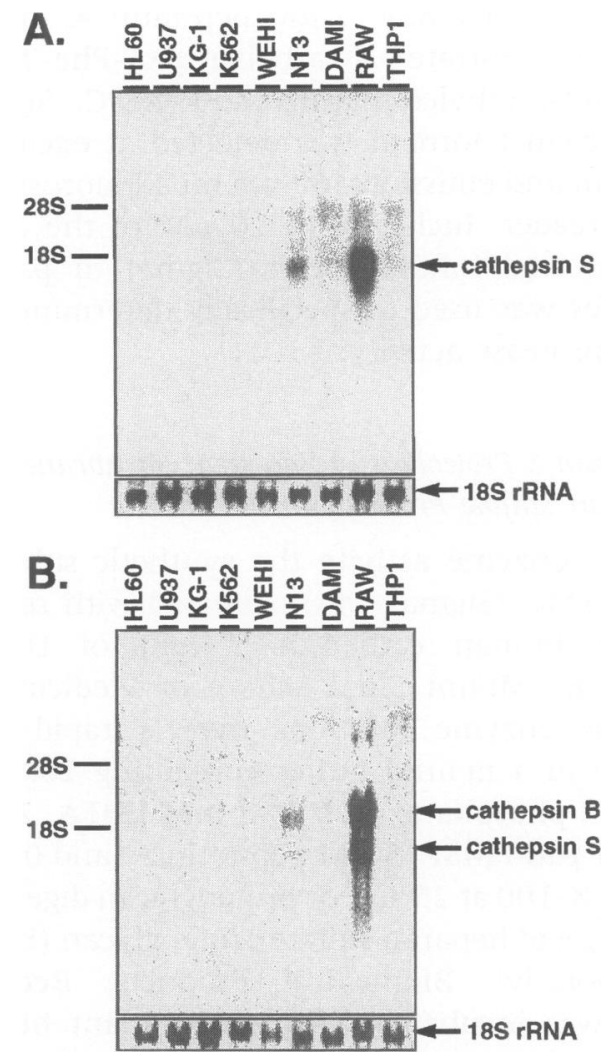

Fig. 1. Expression of cathepsin $S(A)$ and cathepsin B (B) mRNA in blood-derived and macrophage-like cell lines. Total RNA was isolated as described in Materials and Methods from various cell lines and $15 \mu \mathrm{g} / \mathrm{lane}$ was subjected to Northern analysis. RNA blots were probed with ${ }^{32} \mathrm{P}$ labeled cDNA specific for cathepsin $\mathrm{S}$, cathepsin $\mathrm{B}$, or $18 S$ rRNA.

curred as early as $2 \mathrm{hr}$ after treatment with LPS (Fig. 4B).

We were interested in the effect of other activators of macrophages and microglia, such as the cytokines produced and released by activated macrophages/microglia themselves and/or other stimulated cells during an inflammatory process, on the expression of cathepsin S, cathepsin B, and cathepsin L mRNAs. We found that TNF- $\alpha$, IL- $1 \alpha$, IFN- $\gamma$, GM-CSF, IFN- $\alpha$, and PMA decreased the levels of all three transcripts in microglia after $24 \mathrm{hr}$ of treatment (Table 1), which is similar to the effect of LPS.

To examine if the decrease in mRNA levels for cathepsin $S$ after treatment of cells with activators resulted in decreased cathepsin $S$ protein levels, we carried out Western blot analysis with cathepsin S-specific antiserum. When examined for the effects of 24-hr LPS treatment on cells, we found that cathepsin $S$ protein decreased dose- 
A.
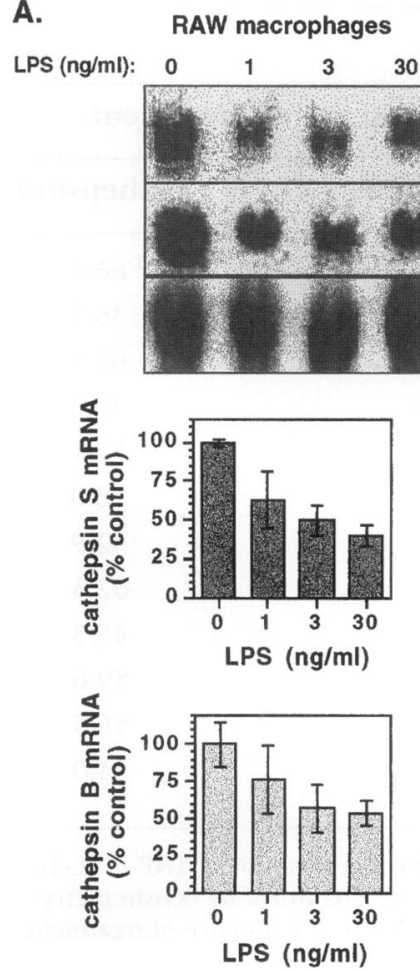

B.
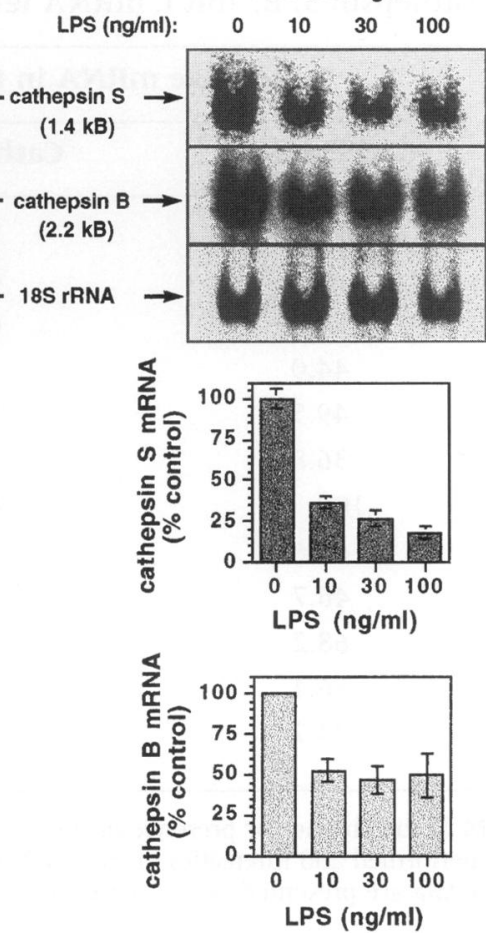

Fig. 2. Decreased cathepsin mRNA in macrophage and microglia cell lines after LPS treatments for $24 \mathrm{hr}$. RAW 264.7 (A) or N13 (B) cells were treated with various doses of LPS for 24 hr as described in Materials and Methods. Total RNA was isolated and $15 \mu \mathrm{g} /$ lane was subjected to Northern analysis. RNA blots were probed with ${ }^{32} \mathrm{P}$-labeled cDNAs specific for cathepsin $S$, cathepsin $\mathrm{B}$, or $18 \mathrm{~S}$ rRNA. Densitometry of RNA bands was performed by phosphorimager. In the graphs, relative intensity in the absence of LPS treatment is taken as control $(100 \%)$ and data are normalized to levels of $18 \mathrm{~S}$ rRNA. Data represent mean \pm SEM of three independent experiments.
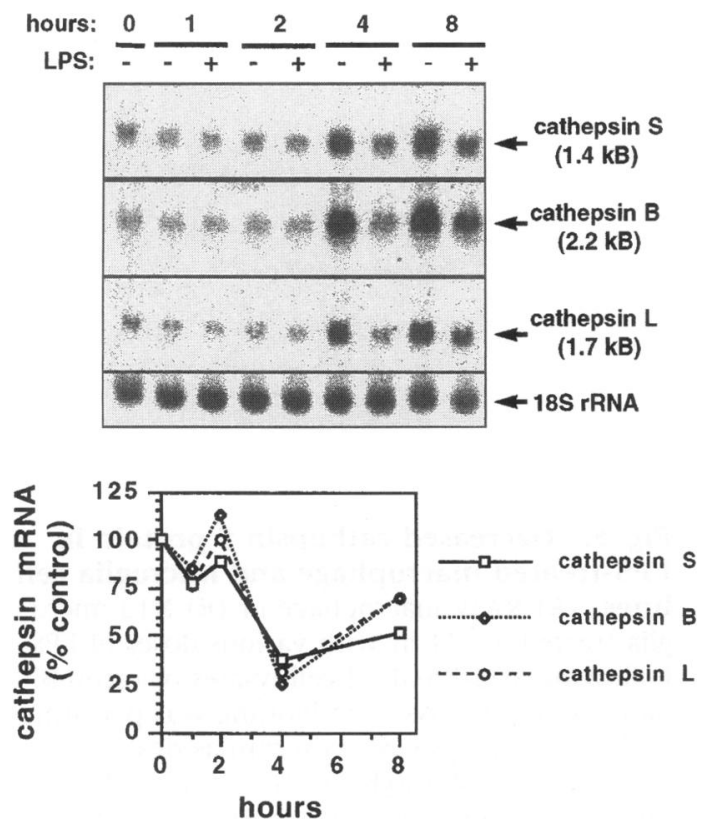

Fig. 3. Time-course analysis of decreased cathepsin S, B, and L mRNA levels in macrophages. RAW 264.7 cells were treated in the presence or absence of LPS (30 ng/ml) for various durations. At each time point cells were collected total RNA was isolated and Northern analysis and densitization were performed as described. The relative intensity in the absence of LPS treatment for each time point (MSFM alone) is taken as control $(100 \%)$.
A.

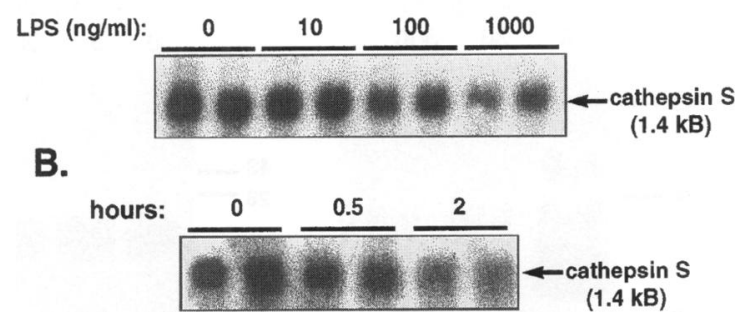

Fig. 4. Decreased cathepsin $S$ mRNA in LPStreated primary rat alveolar macrophages. Total RNA was isolated from $5 \times 10^{6}$ rat alveolar macrophages treated with increasing concentrations of LPS for $4 \mathrm{hr}$ (A) or treated with $100 \mathrm{ng} / \mathrm{ml}$ LPS for various durations (B) and subject to Northern analysis (15-20 $\mu \mathrm{g} /$ lane). RNA blots were probed with ${ }^{32} \mathrm{P}$ labeled cDNAs specific for cathepsin S.

dependently in RAW macrophages (Fig. 5A) and in N13 microglia (Fig. 5B). In both cases, a decrease of $50 \%$ to $75 \%$ in cathepsin $\mathrm{S}$ protein was observed upon 24-hr treatment with $300 \mathrm{ng} / \mathrm{ml}$ of LPS. In addition, IFN- $\gamma$ treatment of RAW macrophages decreased cathepsin $S$ protein in a dose-dependent manner (Fig. 5C). These data are in agreement with the decreased mRNA levels observed above following LPS and IFN- $\gamma$ treatment of cells. 
Table 1. Effects of various cytokines on cathepsin $S, B$, and $L$ mRNA levels

\% Relative mRNA in the Absence of Treatment

\begin{tabular}{|c|c|c|c|c|}
\hline \multirow[b]{2}{*}{ Agent } & \multirow[b]{2}{*}{ Concentration } & \\
\hline & & Cathepsin S & Cathepsin B & Cathepsin L \\
\hline TNF- $\alpha$ & $0.1 \mathrm{ng} / \mathrm{ml}$ & 70.2 & 59.5 & 66.4 \\
\hline TNF- $\alpha$ & $1.0 \mathrm{ng} / \mathrm{ml}$ & 38.1 & 47.3 & 36.7 \\
\hline TNF- $\alpha$ & $10 \mathrm{ng} / \mathrm{ml}$ & 59.9 & 61.0 & 67.5 \\
\hline $\mathrm{IL}-1 \alpha$ & $0.1 \mathrm{ng} / \mathrm{ml}$ & 44.0 & 36.9 & 40.0 \\
\hline IL- $1 \alpha$ & $1.0 \mathrm{ng} / \mathrm{ml}$ & 49.5 & 55.1 & 57.1 \\
\hline IL- $1 \alpha$ & $10 \mathrm{ng} / \mathrm{ml}$ & 36.8 & 8.5 & 18.0 \\
\hline GM-CSF & $0.1 \mathrm{ng} / \mathrm{ml}$ & 100 & 64.3 & 82.9 \\
\hline GM-CSF & $1.0 \mathrm{ng} / \mathrm{ml}$ & 69.6 & 53.2 & 62.3 \\
\hline GM-CSF & $10 \mathrm{ng} / \mathrm{ml}$ & 46.7 & 38.2 & 45.3 \\
\hline IFN- $\alpha$ & $3 \mathrm{U} / \mathrm{ml}$ & 68.2 & 53.1 & 59.0 \\
\hline IFN- $\alpha$ & $30 \mathrm{U} / \mathrm{ml}$ & 56.4 & 49.6 & 56.3 \\
\hline IFN- $\gamma$ & $30 \mathrm{U} / \mathrm{ml}$ & 23.7 & 25.5 & 24.0 \\
\hline
\end{tabular}

N13 microglial cells were treated for $24 \mathrm{hr}$ in MSFM in the absence or presence of the indicated concentrations of TNF- $\alpha$, IL-1 $\alpha$, IFN- $\gamma$, GM-CSF, and IFN- $\alpha$. Northern analysis was performed and intensities of specific bands were quantified by densitometry. All values were then standardized to $18 \mathrm{~S}$ rRNA and data are presented as \% relative level of mRNA in the absence of treatment.

A

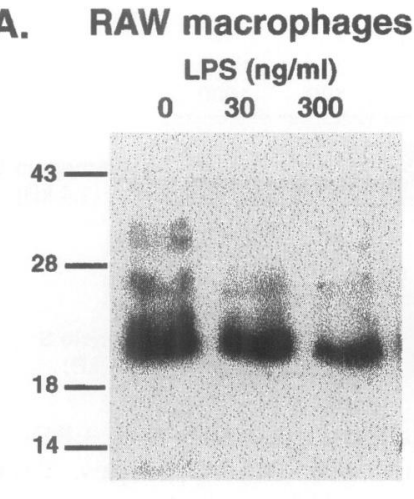

RAW macrophages

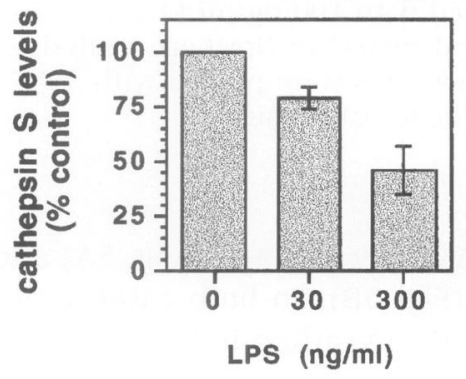

B. N13 microglia
LPS (ng/ml)

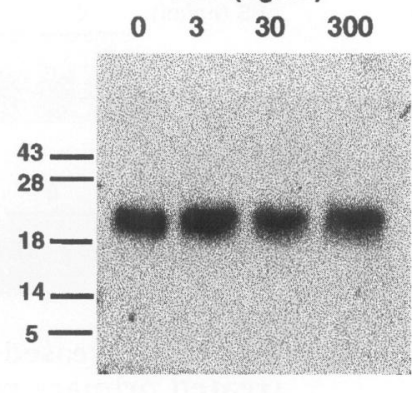

N13 microglia

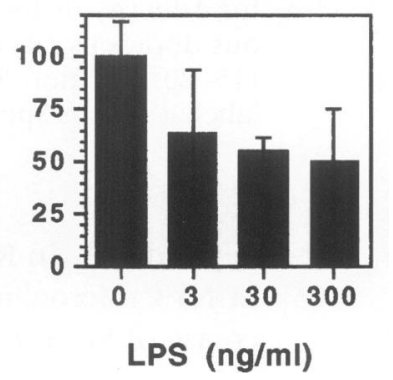

Fig. 5. Decreased cathepsin $S$ protein in LPS-treated macrophage and microglia cell lines. (A) RAW macrophage or (B) N13 microglia treated for $24 \mathrm{hr}$ with various doses of LPS. Following SDS-PAGE of cell lysates or recombinant cathepsins, Western blotting was performed with anti-cathepsin S antiserum as described in Materials and Methods. In the graphs, relative intensity in the absence of treatment is taken as control $(100 \%)$. Data represent mean \pm SEM of three experiments for RAW cells and mean \pm SEM of two experiments for N13 cells.

We next examined whether RAW 264.7 macrophages and $\mathrm{N} 13$ microglial cells regulate their cathepsin $S$ proteolytic activity in response to activating signals. We used the inhibition by active-site cysteine protease inhibitor, E64, as an indication of specificity to enable us to determine cysteine protease activity. We also used preincubation of samples at neutral $\mathrm{pH}$ to specifically 

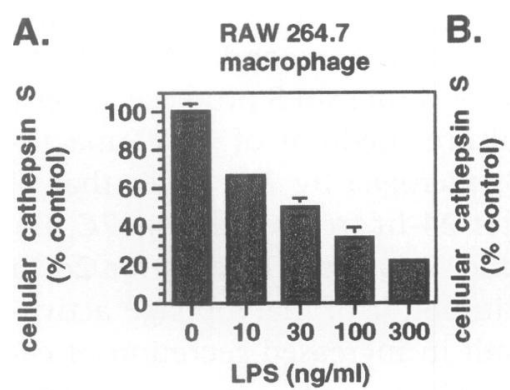

C.

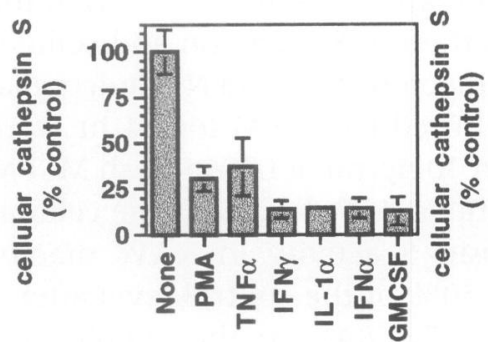

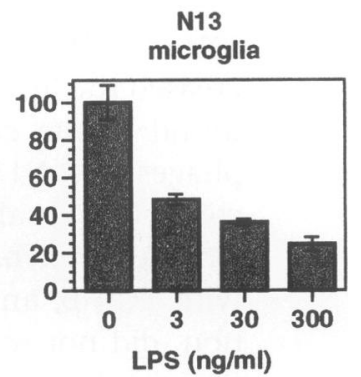

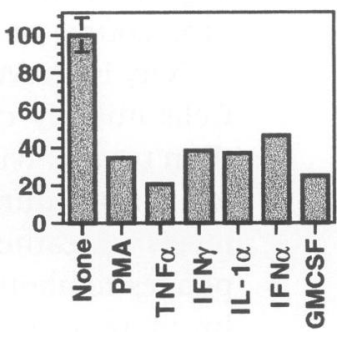

Fig. 6. Effects of activating agents on cellular cathepsin $S$ protease activity in macrophage and microglia cell lines. Cells were treated with various doses of LPS, or with $10 \mathrm{nM}$ PMA, 20 $\mathrm{ng} / \mathrm{ml} \mathrm{TNF}-\alpha, 50 \mathrm{U} / \mathrm{ml}$ IFN- $\gamma, 20 \mathrm{ng} / \mathrm{ml} \mathrm{IL-} 1 \alpha, 50$

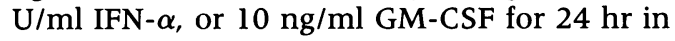
MSFM. Cathepsin S protease activity was measured in cell lysates of RAW macrophages (A and C) or N13 microglia (B and D) from 24-hr-treated cells utilizing the fluorogenic substrate Z-FR-AMC as described in Materials and Methods. Data represent mean \pm SEM of three experiments measuring E64inhibitable cathepsin S activity. Activity in the absence of LPS treatment is taken as control $(100 \%)$.

C.

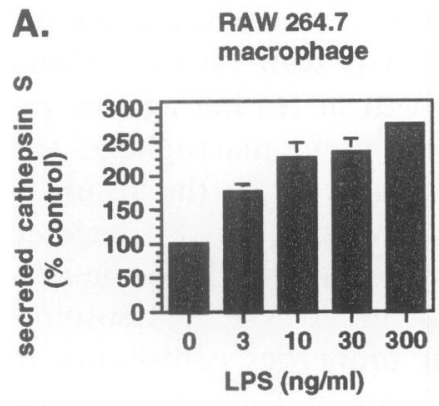

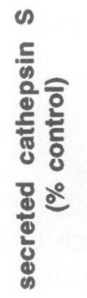

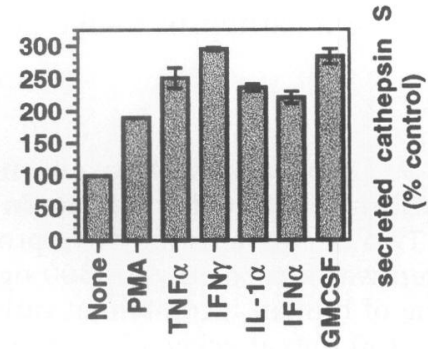

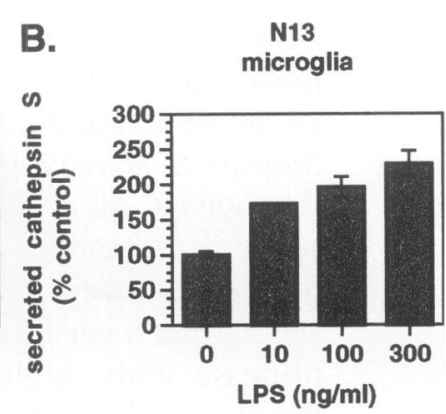

D.

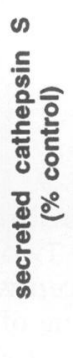

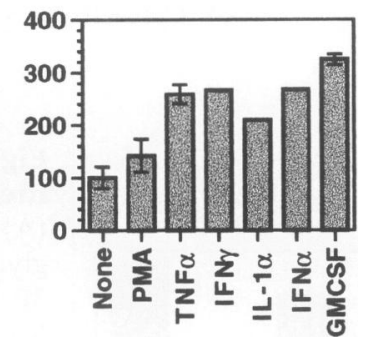

Fig. 7. Effects of activating agents on secreted cathepsin $S$ protease activity in macrophage and microglia cell lines. Cells were treated with various doses of LPS, or with $10 \mathrm{nM}$ PMA, $20 \mathrm{ng} / \mathrm{ml} \mathrm{TNF-} \alpha, 50 \mathrm{U} / \mathrm{ml}$ IFN- $\gamma, 20 \mathrm{ng} / \mathrm{ml}$ IL- $1 \alpha, 50 \mathrm{U} / \mathrm{ml}$ IFN- $\alpha$, or $10 \mathrm{ng} / \mathrm{ml} \mathrm{GM-CSF}$ for $24 \mathrm{hr}$ in MSFM. Cathepsin S protease activity was measured in the conditioned medium of RAW macrophages (A and C) or N13 microglia (B and D) from 24-hr-treated cells utilizing the fluorogenic substrate Z-FR-AMC as described in Materials and Methods. Data represent mean \pm SEM of three experiments measuring E64-inhibitable cathepsin S activity. Activity in the absence of LPS treatment is taken as control $(100 \%)$. determine cathepsin S activity, since other cysteine lysosomal proteinases become irreversibly inactivated after prolonged incubation at neutral pH $(7,9)$. Just as LPS had decreased mRNA expression, LPS decreased the levels of cathepsin $S$ protease activity in both RAW and $\mathrm{N} 13$ cells in a dose-dependent manner (Fig. 6A, B). A 50\% decrease in cellular cathepsin $\mathrm{S}$ activity was achieved in RAW macrophages and N13 microglia by LPS at $30 \mathrm{ng} / \mathrm{ml}$ and $3 \mathrm{ng} / \mathrm{ml}$, respectively. Cathepsin $S$ activity decreased by $>75 \%$ in response to $300 \mathrm{ng} / \mathrm{ml}$ of LPS in both RAW and
N13 cells. Similarly, 24-hr treatment with PMA, TNF- $\alpha$, IFN- $\gamma$, IL- $1 \alpha$, IFN- $\alpha$, and GM-CSF dramatically decreased the levels of cellular cathepsin S activity in RAW and N13 cells (Fig. 6C, D); this is consistent with the observed decrease in levels of cathepsin S mRNA by these agents.

In contrast to the decreased level of cathep$\sin \mathrm{S}$ activity in cells, we found that LPS dosedependently increased secreted cathepsin $S$ activity from RAW or N13 cells (Fig. 7A, B). A low concentration of $3 \mathrm{ng} / \mathrm{ml}$ LPS increased cathep$\sin \mathrm{S}$ activity to about 1.8 times control levels in 
A.
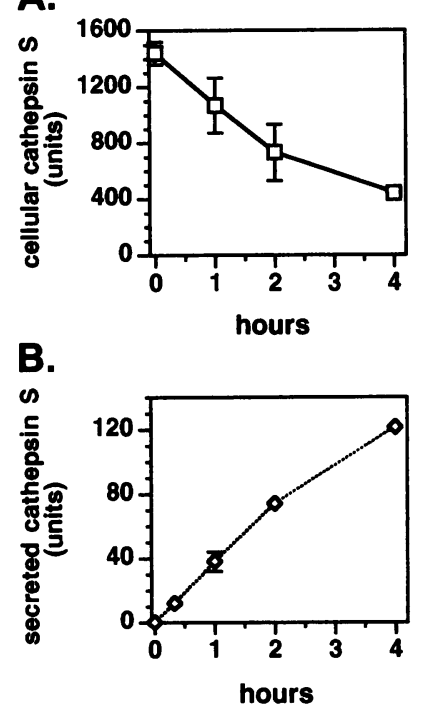

Fig. 8. Time-course analysis of LPS on macrophage and microglia cathepsin $S$ protease activity. RAW 264.7 cells were both initially cultured and treated in MSFM with $30 \mathrm{ng} / \mathrm{ml}$ LPS for various durations, and cathepsin $S$ protease activity was measured in cell lysates (A) and in C.M. (B) utilizing the fluorogenic substrate Z-FR-AMC. Data represent mean \pm SEM of representative experiment measuring E64-inhibitable cathepsin S activity.

RAW-conditioned medium and to about 2.1 times control levels in N13-conditioned medium following 24-hr treatment. LPS at $300 \mathrm{ng} / \mathrm{ml}$ increased cathepsin S activity 2.7-fold in RAWand 3.1-fold in N13-conditioned medium. Also, we found that the agent PMA and the cytokines TNF- $\alpha$, IFN- $\gamma$, IL- $1 \alpha$, IFN- $\alpha$, and GM-CSF increased the levels of cathepsin $S$ protease activity found in the culture medium of RAW macrophages and N13 microglia by 2-3 times that of control levels after 24-hr treatment (Fig. 7C, D). On the other hand, treatment of cells for $24 \mathrm{hr}$ with TGF- $\beta$, an inhibitor of macrophage activation, did not result in increased secretion of cathepsin S activity (J. P. Liuzzo and L. A. Devi, unpublished observations). We also followed the time course of cathepsin S secretion and cellular activity in RAW macrophages and N13 microglia. Cells initially cultured in MSFM for $24 \mathrm{hr}$ were then treated with $30 \mathrm{ng} / \mathrm{ml}$ of LPS in fresh MSFM for various durations. LPS decreased the cellular levels of cathepsin S activity in RAW macrophages to about $50 \%$ of the control level after 2 hr of treatment (Fig. 8A). In the conditioned medium it was found that LPS rapidly caused the secretion of cathepsin S activity, which was evident after $15 \mathrm{~min}$ (Fig. 8B). Since the cathepsin $\mathrm{S}$ mRNA and cellular activity were decreased after $24 \mathrm{hr}$ of treatment with activating agents, cathepsin $\mathrm{S}$ activity present in macrophage and microglia C.M. at $24 \mathrm{hr}$ is likely the result of stability at neutral $\mathrm{pH}$ of this rapidly secreted protease. However, we cannot exclude the possibility that a yet-unidentified cysteine lysosomal protease with similar properties contributes to the observed secreted activity. These data suggest that macrophages and microglia, upon activation by cytokines, secrete a cathepsin S-like activity,
A.

B.

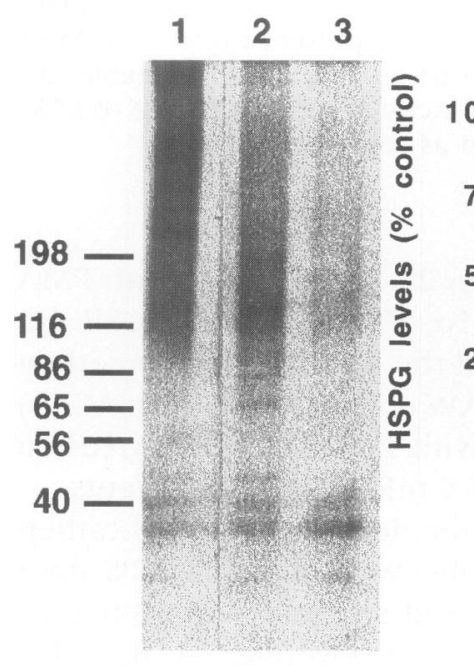

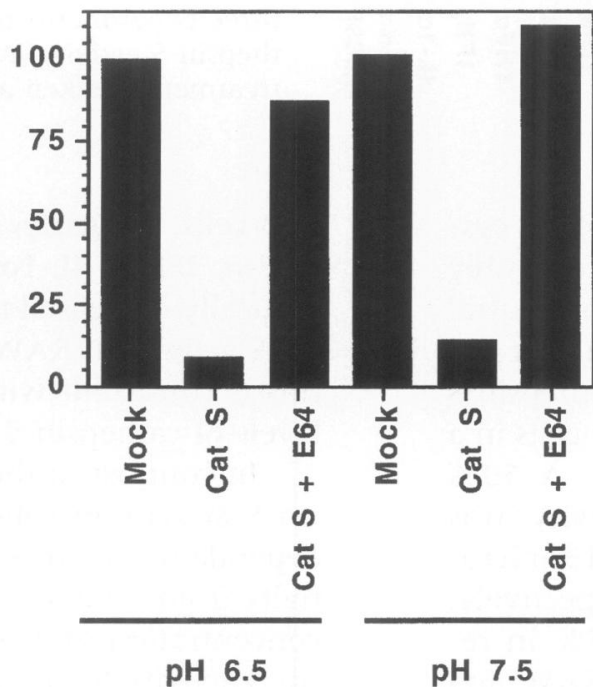

Fig. 9. Proteolysis of basement membrane HSPG by cathepsin S. (A) Two micrograms of native proteoglycan was incubated with $300 \mathrm{ng}$ or $30 \mathrm{ng}$ of human recombinant cathepsin $\mathrm{S}$ for $150 \mathrm{~min}$ at acidic $\mathrm{pH}$ and analyzed as described in Materials and Methods. Lane 1, HSPG incubated with $300 \mathrm{ng}$ cathepsin S and $5 \mu \mathrm{M}$ E64 included in the reaction mixture; lane 2 , HSPG incubated with $30 \mathrm{ng}$ of cathepsin S; lane 3 HSPG incubated with 300 ng cathepsin S. (B) Ten nanograms of recombinant cathepsin $S$ was incubated with $1 \mu \mathrm{g}$ of HSPG (1:1000 substrate: enzyme ratio) for $1.5 \mathrm{hr}$ in sodium phosphate buffer, pH 6.5 or pH 7.5, containing $50 \mu \mathrm{M}$ E64. Mock digestion contained no cathepsin S. Samples were analyzed by silver staining, gels were scanned and desensitized as described. The results represent \% control. 
A.

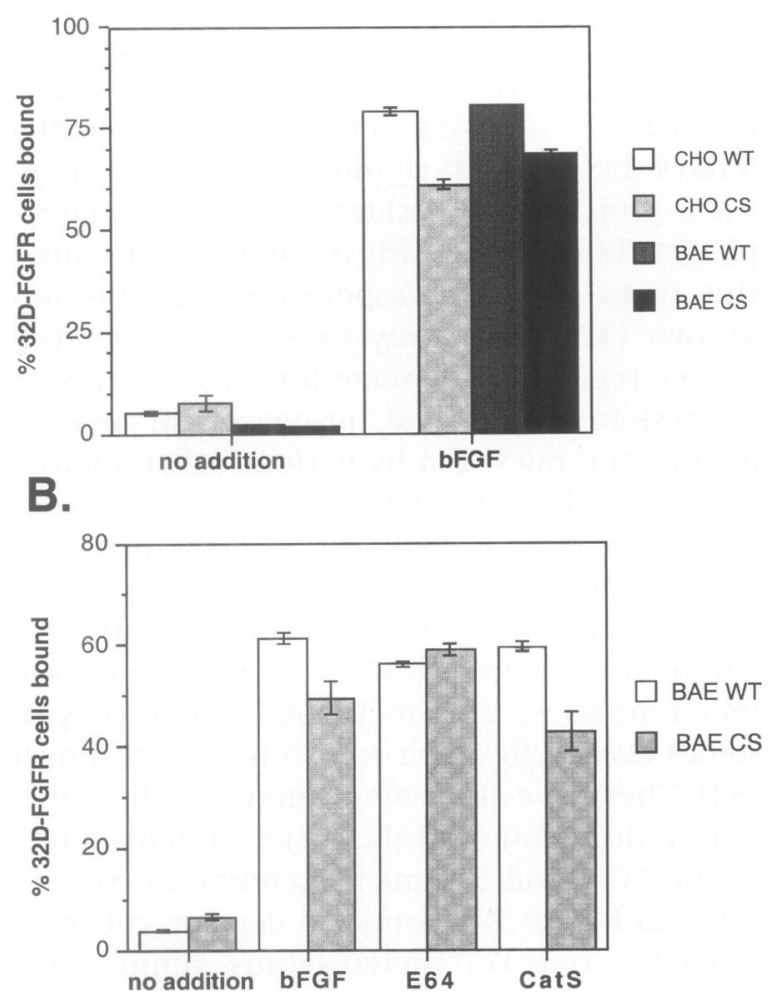

Fig. 10. Proteolysis of HSPG by cathepsin $S$ in vivo attenuates bFGF-dependent cell-cell attachment mediated by FGFRs and HSPGs. (A) Co-cultures of 32D-FGFR-1 suspension cells with four different cell types-CHO or BAE wildtype (WT) cells, or CHO or BAE cells transfected with cathepsin $S$ (CS)-performed in the presence or absence of $10 \mathrm{ng} / \mathrm{ml}$ of bFGF. (B) Comparison of cocultures of 32D-FGFR-1 suspension cells with either wild-type or cathepsin S-transfected BAE cells without bFGF, with bFGF, with bFGF using BAE cells grown in the presence of E64, or with bFGF using BAE cells preincubated with recombinant cathepsin $S$ (CatS).

which in turn may take part in the dissolution of the ECM and its remodeling.

We have previously demonstrated that cathepsin $S$ processes two brain chondroitin proteoglycans, neurocan and phosphacan (11), and the amyloid precursor protein (S. S. Petanceska and L. A. Devi, unpublished observations), which is known to contain chondroitin sulfate modifications $(26,27)$. We investigated whether recombinant cathepsin $\mathrm{S}$ can cleave basement membrane HSPG. Following a 2.5-hr incubation at $\mathrm{pH} 6.5$ of recombinant human cathepsin S, purified basement membrane HSPG was almost completely degraded (Fig. 9A). Including E64 in the reaction mixture completely abolished the degradation of the HSPG. We also compared the ability of cathepsin $\mathrm{S}$ to degrade basement membrane HSPG at a neutral $\mathrm{pH}$ and found that cathepsin $\mathrm{S}$ degraded basement membrane HSPG at both pH 6.5 and $\mathrm{pH} 7.5$ with similar efficiencies (Fig. 9B).

We tested whether exogenous recombinant cathepsin $\mathrm{S}$ could affect the binding of iodinated bFGF ( $\left.{ }^{125} \mathrm{I}-\mathrm{bFGF}\right)$ to cells and affect the bFGFdependent adhesion of 32D-FGFR cells to $\mathrm{CHO}$ cells in co-culture experiments $(17,18)$, and found that exogenous recombinant cathepsin $S$ did not decrease the bFGF-dependent adhesion between these two cell types (data not shown). To overcome the possibility that exogenous cathepsin $S$ is being inhibited by cell surface inhibitors, we overexpressed cathepsin $S$ in cells and examined the effect on cell-derived HSPGs. We transfected $\mathrm{CHO}$ and BAE cells with cathepsin S, which do not express endogenous forms of this enzyme. Northern blot analysis and Western blot analysis confirmed cathepsin S mRNA in transfected cells, and not in untransfected cells, and cathepsin $S$ protease activity was found to be secreted at high levels from unstimulated transfected cells (not shown). This enabled us to test whether cellular cathepsin $S$ had an effect on cellular HSPGs by performing ${ }^{125}$ I-bFGF ligand blotting of wild-type or transfected BAE cell lysates. In autoradiographs of ${ }^{125} \mathrm{I}-\mathrm{bFGF}$ ligand blots, we detected a broad smear of molecules ranging from 100 to $250 \mathrm{kDa}$ in wild-type $\mathrm{BAE}$ cells, which disappeared upon inclusion of soluble heparin-this is characteristic of HSPG (28,29; data not shown). In BAE cells transfected with cathepsin $\mathrm{S}$, the levels of bFGF-binding HSPG was substantially decreased (data not shown), suggesting that secreted cathepsin $S$ might play a role in digesting bFGF-binding HSPGs and that way, facilitate the release of these molecules from cultured cells.

Transfected, adherent $\mathrm{CHO}$ and BAE cells were then used in co-culture experiments to determine the effect on bFGF-dependent attachment of 32D-FGFR-1 cells to HSPGs (18). Attachment of 32D-FGFR-1 cells to wild-type and cathepsin S-transfected CHO cells and BAE cells revealed a $10 \%$ to $20 \%$ decrease in bFGF-dependent attachment (Fig. 10A). This decreased attachment could be inhibited by culturing the adherent cell layer in the presence of the specific, cysteine lysosomal protease inhibitor, E64 (Fig. 10B). Addition of exogenous recombinant cathepsin $S$ to transfected BAE cell cultures fur- 
ther attenuated the bFGF-dependent attachment of 32D-FGFR-1 cells (not shown). This decreased attachment to cathepsin S-transfected cells may be caused by cathepsin $S$ acting on basement membrane HSPG in the adherent endothelial cell cultures.

\section{Discussion}

Tissue macrophages and microglia are versatile, dynamic cells that, under normal circumstances, are quiescent, but respond aggressively to external stimuli. Cathepsin $S$ is a cysteine lysosomal protease strictly expressed in these mononuclear phagocytic cells. We report that LPS, the prototypic agent used to stimulate macrophage activation, cytokines commonly found associated with inflammatory processes, e.g., TNF- $\alpha$, IFN- $\gamma$, IL$1 \alpha$, IFN- $\alpha$, and GM-CSF, and a PKC activator stimulate the release of proteolytically active cathepsin $\mathrm{S}$ into a neutral $\mathrm{pH}$ environment. Cathepsin $\mathrm{S}$ activity in the medium remains even after $24 \mathrm{hr}$, making it an ideal candidate for extracellular proteolysis in vivo. Along with increased secretion, these agents decrease the cellular level of cathepsin S activity in macrophages and microglia after $24 \mathrm{hr}$ of treatment. The maximum amount secreted accounts for only $5 \%$ and $30 \%$ of total cellular cathepsin S activity in RAW macrophages and N13 microglia, respectively. The lower percentage of total cathepsin $S$ released by RAW cells is consistent with our finding that macrophages contain higher levels of basal cathepsin S activity than microglial cells. Decreased cellular cathepsin $S$ activity is due to increased secretion and decreased mRNA levels, indicating that cysteine lysosomal proteinases are negatively regulated by long-term activating signals.

In this study, using cell lines and primary cells, we have extended our previous findings that cathepsin $S$ secretion and expression in macrophages and microglia can be regulated by inflammatory agents. Previously, we reported a 2- to 3-fold increase in secretion of cathepsin $\mathrm{S}$ activity from LPS-stimulated, thioglycolateelicited macrophages compared to LPS-stimulated resident macrophages (11). We have also reported an in vivo up-regulation of cathepsin $S$ mRNA in microglia following entorhinal cortex lesion in rat brain (11); the molecular signals that regulate this phenomenon remain to be elucidated. Cathepsin B has not been found to be secreted from either unstimulated or ac- tivated peritoneal macrophages elicited by mineral oil, endotoxin, carrageenan, or thioglycolate $(30,31)$. Regulation of cathepsin L has been described in murine thioglycolateelicited peritoneal macrophages, whereby after 5 days they contain significantly more cathepsin L protein than resident peritoneal macrophages; however, in this in vivo circumstance, the agents directly responsible are also unknown (32). Our study here further demonstrates regulation of secretion and expression of cysteine lysosomal proteases in macrophages and microglia by various inflammatory mediators that may be present under various circumstances in vivo, e.g., CNS injury and nerve degeneration $(1,4,33)$.

The cysteine proteinases of the cathepsin family are able to degrade a wide range of protein substrates, thus their localization in lysosomes exemplifies their role in protein turnover (34). They have also been demonstrated to function in degradation of the major proteins found in the ECM and basement membranes. Specifically, cathepsin B is found to degrade collagens (including type IV), proteoglycans, laminin, and fibronectin (35-38) and cathepsin $\mathrm{L}$ is found to degrade collagen, elastin, fibronectin, and laminin $(39-41)$ in vitro at acidic $\mathrm{pH}$. We and others have demonstrated that cathepsin $\mathrm{S}$ has the ability to degrade laminin, fibronectin, collagens, elastin, and chondroitin sulfate proteoglycan (CSPG) at both neutral and acidic pH (9-12). Therefore, cathepsin S may function extracellularly for long durations to proteolyse proteins of the interstitial matrix.

Macrophage recruitment during immune and inflammatory processes requires adhesion to endothelium, extravasation through the vessel wall, and migration into the appropriate tissue. This process, which mimics tumor cell metastasis, requires proteases to degrade the ECM and the basement membrane surrounding blood vessels (42). For a role of cysteine proteinases in macrophage degradation of ECM and basement membrane components during inflammation it is important to demonstrate extracellular active forms of these enzymes. Cathepsin B is secreted from malignant tumors in an active high-molecular-weight form that is stable at neutral $\mathrm{pH}$ and this correlates with metastatic potential (43). Cathepsin L precursors are also found extracellularly via secretion from transformed and nontransformed fibroblasts, but is inactive at neutral $\mathrm{pH}$ and becomes an active enzyme only at $\mathrm{pH} 3.0$ $(34,44)$. Since secreted precursor cathepsin $L$ is 
inactive at neutral $\mathrm{pH}$ and precursor cathepsin $\mathrm{B}$ is active but secreted only from malignant cells, our demonstration of increased secreted active cathepsin S from stimulated cells of the mononuclear-phagocytic system suggests that cathepsin S could contribute substantially to the extracellular degradation. Alternatively, the increase in extracellular cathepsin S-like activity can be due to down-regulation of the constitutive secretion of cystatin C, as observed in activated monocytes and macrophages (45).

Macrophages and microglia secrete well over 100 products when activated, and this complex process must be highly regulated by external stimuli of both microbial and mammalian origin $(3,4)$. LPS is a potent stimulant for macrophages and microglia and in high concentrations may result in a full activation state. The proinflammatory cytokines TNF $\alpha$, IFN- $\alpha / \beta / \gamma$, IL-1- $\alpha / \beta$, MCSF, and GM-CSF can all be secreted by LPSinduced macrophages and microglia and thus may act to potentiate the inflammatory response in an autocrine manner $(46,47)$. In addition, they may be secreted by other activated cells and act on macrophages or microglia in a paracrine manner; for example, IL-1 is released by B cells, natural killer cells, neutrophils, endothelial cells (EC), and astrocytes (4). Cytokines derived from macrophages or other cells may in turn regulate the levels of other cytokines; IFN- $\gamma$ enhances macrophage release of TNF- $\alpha$; IL- 1 and TNF- $\alpha$ induce each other's release from EC and macrophages; and IL-1 and TNF- $\alpha$ stimulate fibroblasts and EC to release GM-CSF $(48-50)$. How these complex networks of signals regulate the secretory capacity of macrophages and microglia is not well understood. We provide evidence that they can regulate the cysteine lysosomal proteases, in particular cathepsin S, which may be important for extracellular action against matrix and basement membrane proteins. Cathepsin $S$ joins the growing list of secretory products of stimulated macrophages and microglia that may act to modulate tissue remodeling.

HSPG has been described as a multi-domain, multifunctional molecule that binds growth factors and extracellular matrix molecules such as type IV collagen, laminin, and fibronectin (14). Such interactions may result in control of cell proliferation and differentiation. In this study, we have demonstrated that purified recombinant cathepsin S can degrade HSPG derived from Engelbreth-Holm-Swarm tumor, which is similar to HSPG found in the basement membrane of many tissues including skin, liver, blood vessels, and kidney. HSPGs are important low-affinity cellsurface and ECM receptors for bFGF which facilitate bFGF binding to FGF receptors (FGFRs) and promote their dimerization (16). Perlecan, the large basement membrane HSPG, was previously found to induce high-affinity binding to cells deficient in heparan sulfate and to soluble FGF receptors, and promote mitogenesis and angiogenesis (15). We have previously shown that HSPG on adherent cells in culture can promote the bFGF-dependent attachment of suspension cells containing FGFRs (32D-FGFR cells) but are deficient in HSPGs (18). Utilizing this assay, we now demonstrate that expression of cathepsin $S$ in HSPG-bearing adherent cells that do not normally express cathepsin $S$ moderately attenuates the bFGF-dependent attachment of 32D-FGFR cells. Whether cells attach predominantly to the HSPGs on the cell surface or the ECM produced by the adherent cell layer is not yet determined. In addition to attaching to cell-surface HSPG, 32D-FGFR cells could attach to basement membrane HSPG since the attachment of these cells occurs at the boundaries or junctions between adherent cells where basement membrane HSPG is localized (51-53). Proteoglycan shedding from cultured cells has been known for a long time, although the specific proteases involved remain elusive (54). Here we demonstrate a role for secreted cathepsin $S$ in the regulation of bFGFbinding of HSPG in the ECM.

In summary, we have shown that cellular cathepsin levels are negatively regulated in macrophages and microglia in response to LPS and other activating inflammatory cytokines. However, these activating agents are able to stimulate macrophages and microglia to significantly increase their secretion of cathepsin S, which remains active at neutral $\mathrm{pH}$ for long duration. Cathepsin $S$ had been shown to process ECM molecules, and here we demonstrate that it also degrades basement membrane HSPG. These observations suggest that it might be involved in the regulation of heparan sulfate interactions with important signaling molecules.

\section{Acknowledgments}

This work was supported in part by National Institute of Health grants NS 26880 and NS K04 1788 (to L. A. D.). 


\section{References}

1. Perry VH, Gordon S. (1991) Macrophages and the nervous system. Int. Rev. Cytol. 125: 203-244.

2. Adams DO, Hamilton TA. (1984) The cell biology of macrophage activation Annu. Rev. Immunol. 2: 283-318.

3. Page RC, Davies P, Allison AC. (1978) The macrophage as a secretory cell Int. Rev. Cytol. 52: 119157.

4. Nathan CF. (1987) Secretory products of macrophages. J. Clin. Invest. 79: 319-326.

5. Gelb BD, Shi GP, Heller M, et al. (1997) Structure and chromosomal assignment of the human cathepsin K gene. Genomics 41: 258-262.

6. Kirschke H. (1994) Cathepsin S and related lysosomal endopeptidases. Methods Enzymol. 244: 500511.

7. Bromme D, Okamoto $\mathrm{K}$, Wang BB, Biroc S. (1996) Human cathepsin O2, a matrix proteindegrading cysteine protease expressed in osteoclasts. Functional expression of human cathepsin $\mathrm{O} 2$ in Spodoptera frugiperda and characterization of the enzyme. J. Biol. Chem. 271: 2126-2132.

8. Bromme D, Steinert A, Friebe S, Fittkau S, Wiederanders B, Kirschke H. (1989) The specificity of bovine spleen cathepsin S. A comparison with rat liver cathepsins L and B. Biochem. J. 264: $475-481$.

9. Kirschke H, Wiederanders B, Bromme D, Rinne A. (1989) Cathepsin S from bovine spleen. Purification distribution intracellular localization and action on proteins. Biochem. J. 264: 467-473.

10. Maciewicz RA, Etherington DJ. (1988) A comparison of four cathepsins (B, L, N and S) with collagenolytic activity from rabbit spleen. Biochem. $J$. 256: 433-440.

11. Petanceska S, Canoll P, Devi LA. (1996) Expression of rat cathepsin S in phagocytic cells. J. Biol. Chem. 271: 4403-4409.

12. Shi G-P, Munger JS, Meara JP, Rich DH, Chapman HA. (1992) Molecular cloning and expression of human alveolar macrophage cathepsin S, an elastinolytic cysteine protease. J. Biol. Chem. 267: 7258-7262.

13. Shi G-P, Webb AC, Foster KE, et al. (1994) Human cathepsin S: chromosomal localization, gene structure, and tissue distribution. J. Biol. Chem. 269: 11530-11536.

14. Basilico C, Moscatelli D. (1992) The FGF family of growth factors and oncogenes. Adv. Cancer Res. 59: 115-165.

15. Aviezer D, Hecht D, Safran M, Eisinger M, David G, Yayon A. (1994) Perlecan basal lamina proteoglycan, promotes basic fibroblast growth factorreceptor binding, mitogenesis, and angiogenesis. Cell 79: 1005-1013.

16. Schlessinger J, Lax I, Lemmon M. (1995) Regulation of growth factor activation by proteoglycans: what is the role of the low affinity receptors? Cell 83: $357-360$.

17. Liuzzo JP, Moscatelli D. (1996) Human leukemia cell lines bind basic fibroblast growth factor (FGF) on FGF receptors and heparan sulfates: downmodulation of FGF receptors by phorbol ester. Blood 87: 245-255.

18. Richard C, Liuzzo JP, Moscatelli D. (1995) Fibroblast growth factor-2 can mediate cell attachment by linking receptors and heparan sulfate proteoglycans on neighboring cells. J. Biol. Chem. 270: 24188-24196.

19. Roghani M, Mansukhani A, Dell'Era P, et al. (1994) Heparin increases the affinity of basic fibroblast growth factor for its receptor but is not required for binding. J. Biol. Chem. 269: 39763984.

20. Petanceska S, Burke S, Watson SJ, Devi LA. (1994) Differential distribution of messenger RNAs for cathepsins B, L and S in adult rat brain: an in situ hybridization study. Neuroscience 59: 729-730.

21. Petanceska S, Devi L. (1992) Sequence analysis, tissue distribution, and expression of rat cathepsin S. J. Biol. Chem. 267: 26038-26043.

22. Reddy VY, Zhang Q-Y, Weiss SJ. (1995) Pericellular mobilization of the tissue-destructive cysteine proteinases, cathepsins $\mathrm{B}, \mathrm{L}$, and $\mathrm{S}$, by human monocyte-derived macrophages. Proc. Natl. Acad. Sci. U.S.A. 92: 3849-3853.

23. Reilly JJ, Mason RW, Chen P, Joseph LJ, Sukhatme VP, Yee R. (1989) Synthesis and processing of cathepsin L, an elastase, by human alveolar macrophages. Biochem. J. 257: 493-498.

24. Reilly JJ, Chen P, Sailor LZ, Mason RW, Chapman HA. (1990) Uptake of extracellular enzyme by a novel pathway is a major determinant of cathepsin L levels in human macrophages. J. Clin. Invest. 86: $176-183$.

25. Li Q, Ding L, Bever CT. (1998) Interferon-c induces cathepsin B expression in a human macrophage-like cell line by increasing both transcription and mRNA stability. Int. J. Mol. Med. 2: 181186.

26. Schubert D, Schroeder R, LaCorbiere M, Saitoh T, Cole G. (1988) Amyloid beta protein precursor is possibly a heparan sulfate proteoglycan core protein. Science 241: 223-226.

27. Shioi J, Anderson JP, Ripellino JA, Robakis NK. (1992) Chondroitin sulfate proteoglycan form of the Alzheimer's beta-amyloid precursor. J. Biol. Chem. 267: 13819-13822.

28. Brunner G, Gabrilove J, Rifkin DB, Wilson EL. (1991) Phospholipase $C$ release of basic fibroblast growth factor from human bone marrow cultures as a biologically active complex with a phosphatidylinositol-anchored heparan sulfate proteoglycan. J. Cell. Biol. 114: 1275-1283.

29. Saksela O, Moscatelli D, Sommer A, Rifkin DB. (1988) Endothelial cell-derived heparan sulfate 
binds basic fibroblast growth factor and protects it from proteolytic degradation. J. Cell Biol. 107: 743-751.

30. Recklies AD, Mort JS, Poole AR. (1982) Secretion of a thiol proteinase from mouse mammary carcinomas and its characterization. Cancer Res. 42: 1026-1032.

31. Morland B, Pedersen A. (1979) Cathepsin B activity in stimulated mouse peritoneal macrophages. Lab. Invest. 41: 379-384.

32. Portnoy DA, Erickson AH, Kochan J, Ravetch JV, Unkeless JC. (1986) Cloning and characterization of a mouse cysteine proteinase. J. Biol. Chem. 261: 14697-14703.

33. Giulian D, Corpuz M. (1993) Microglial secretion products and their impact on the nervous system. Adv. Neurol. 59: 315-320.

34. Mason RW, Wilcox D. (1993) Chemistry of lysosomal cysteine proteinases. Adv. Cell Mol. Biol. Memb. 1: 81-116.

35. Morrison RIG, Barrett AJ, Dingle JT, Prior D. (1973) Cathepsins BI and D. Action on human cartilage proteoglycans. Biochim. Biophys. Acta 302: 411-419.

36. Isemura $M$, Yosizawa Z, Takahashi $\mathrm{K}$, Kosaka H, Kojima N, Ono T. (1981) Characterization of porcine plasma fibronectin and its fragmentation by porcine liver cathepsin B. J. Biochem. 90: 1-9.

37. Burleigh MC, Barrett AJ, Lazarus GS. (1974) Cathepsin Bl. A lysosomal enzyme that degrades native collagen. Biochem. J. 137: 387-398.

38. Buck MR, Karustis DG, Day NA, Honn KV, Sloane BF. (1992) Degradation of extracellular-matrix proteins by human cathepsin $\mathrm{B}$ from normal and tumour tissues. Biochem. J. 282: 273-278.

39. Gal S, Gottesman MM. (1986) The major excreted protein of transformed fibroblasts is an activable acid-protease. J. Biol. Chem. 261: 1760-1765.

40. Kirschke H, Kembhavi AA, Bohley P, Barrett AJ. (1982) Action of rat liver cathepsin $L$ on collagen and other substrates. Biochem. J. 201: 367-372.

41. Mason RW, Johnson DA, Barrett AJ, Chapman HA. (1986) Elastinolytic activity of human cathepsin L. Biochem. J. 233: 925-927.

42. Liotta LA. (1986) Tumor invasion and metastases-role of the extracellular matrix. Cancer Res. 46: $1-7$.

43. Sloane BF. (1990) Cathepsin B and cystatins: evidence for a role in cancer progression. Semin. Cancer Biol. 1: 137-152.
44. Mason RW, Wilcox D, Wikstrom P, Shaw EN. (1989) The identification of active forms of cysteine proteinases in Kirsten-virus-transformed mouse fibroblasts by use of a specific radiolabelled inhibitor. Biochem. J. 257: 125-129.

45. Warfel AH, Zucker-Franklin D, Frangione B, Ghiso J. (1987) Constitutive secretion of cystatin $\mathrm{C}$ (gamma-trace) by monocytes and macrophages and its down-regulation after stimulation. J. Exp. Med. 166: 1912-1917.

46. Perry VH, Andersson P-B, Gordon S. (1993) Macrophages and inflammation in the central nervous system. Trends Neurosci. 16: 268-273.

47. Rappolee DA, Werb Z. (1992) Macrophage-derived growth factors. Curr. Top. Microbiol. Immunol. 181: 87-140.

48. Broudy VC, Kaushansky K, Harlan JM, Adamson JW. (1987) Interleukin 1 stimulates human endothelial cells to produce granulocyte-macrophage colony-stimulating factor and granulocyte colonystimulating factor. J. Immunol. 139: 464-468.

49. Broudy VC, Kaushansky K, Segal GM, Harlan JM, Adamson JW. (1986) Tumor necrosis factor type alpha stimulates human endothelial cells to produce granulocyte/macrophage colony-stimulating factor. Proc. Natl. Acad. Sci. U.S.A. 83: 7467-7471.

50. Munker R, Gasson J, Ogawa M, Koeffler HP. (1986) Recombinant human TNF induces production of granulocyte-monocyte colony-stimulating factor. Nature 323: 79-82.

51. Heremans A, De Cock B, Cassiman JJ, Van den Berghe H, David G. (1990) The core protein of the matrix-associated heparan sulfate proteoglycan binds to fibronectin. J. Biol. Chem. 265: 87168724.

52. Clement B, Yamada Y. (1990) A Mr 80K hepatocyte surface protein(s) interacts with basement membrane components. Exp. Cell Res. 187: 320323.

53. Singer II, Scott S, Kawka DW, Hassell JR. (1987) Extracellular matrix fibers containing fibronectin and basement membrane heparan sulfate proteoglycan coalign with focal contacts and microfilament bundles in stationary fibroblasts. Exp. Cell Res. 173: 558-571.

54. Rapraeger AC, Ott VL. (1998) Molecular interactions of the syndecan core proteins. Curr. Opin. Cell Biol. 10: 620-628. 